Mohammad Wasay, MD, FRCP

Ismail A. Khatri, MD

Correspondence to Dr. Wasay:

mohammad.wasay@aku.edu or mohammadwasay@hotmail.com

\section{NEUROLOGY IN PAKISTAN: GROWING BURDEN, LOW ON PRIORITY, AND A HOPE TO KEEP ALIVE}

Neurology is one of the most underrecognized and underappreciated specialties in Pakistan. ${ }^{1}$ The beginnings of clinical and academic neurology in Pakistan can be traced to the 1960s when 3 neurology departments were established in 2 major cities of Pakistan: 2 in Karachi and 1 in Lahore. ${ }^{2,3}$ One of the 2 departments in Karachi was a combined neurology and psychiatry department. ${ }^{2}$

From the onset, neurology was given the status of an optional specialty by the Pakistan Medical and Dental Council (PMDC) for undergraduate medical colleges. This implied that it was not mandatory for medical colleges to have a separate department of neurology for the purpose of recognition by the PMDC. ${ }^{3}$ Unfortunately, this still holds true even after almost 50 years of building a foundation for/clinical and academic neurology. Many of Pakistan's premier medical colleges do not have a separate neurology department. ${ }^{2}$ Only 15 of the 72 medical colleges have a neurology department or neurology faculty. Most of the medical students graduating from these medical colleges do not go through structured neurology teaching by a neurologist. ${ }^{4}$

Currently, there are 15 programs in 7 cities accredited by the College of Physicians and Surgeons of Pakistan for postgraduate training in neurology. These programs are both in public and private sector hospitals and are primarily adult neurology training programs. The programs are not uniform and the trainees do not get equal opportunities and exposure to various aspects of training. The availability of advanced technology, expertise in neurophysiology, neuroradiology, and other specialized areas varies from program to program. The patient population and disease spectrum is also quite different in public and private sector hospitals. The hierarchal supervision, and gradual transition from supervised to independent, differs greatly from institution to institution. The subspecialties of neurology are not realized even among some neurology circles-and only 1 training program offers training in neurophysiology, child neurology, and stroke neurology. The remaining subspecialties are not only underserved but also underacknowledged. Retaining neurologists in Pakistan is an important issue as an alarming number of neurologists are moving out of the country after training because of lack of jobs.

Except for some work on the epidemiology of epilepsy in the Pakistani population in 1980s and 1990s, no large-scale epidemiologic studies have been done on regional neurologic disorders. The incidence or prevalence of major neurologic diseases is not known ${ }^{5}$ and this lack of data translates into a governmental health policy with little focus on neurologic disease. ${ }^{5}$ The burden of stroke, epilepsy, and CNS infections (especially tuberculous meningitis) is a shared experience across all neurology departments and services in the country. The prevalence of stroke is very high because of hypertension, diabetes, and tobacco use. ${ }^{6}$ Tetanus, rabies, and polio are still prevalent with high mortality. ${ }^{7}$ General physicians and patients are realizing that a neurologist is better trained to manage the complex neurologic diseases. However, there is only about 1 neurologist per 1 million people. ${ }^{4,5}$

Pediatric neurology is also a neglected area. There are fewer than 10 pediatric neurologists and only 1 pediatric neurology training facility in the country. Most children are treated either by pediatricians or adult neurologists. ${ }^{8}$

The Pakistan Society of Neurology (PSN) represents the professional interests of neurologists and provides a platform for advocacy on behalf of patients with neurologic illnesses. Under the PSN umbrella, subspecialty societies focusing on headache, stroke, and epilepsy are also functioning. PSN is now almost 2 decades old and held its 19th Annual Meeting in the spring of 2012. It is a valuable forum to discuss original research, promote neurology education, and foster advocacy. The PSN also holds a winter annual update meeting that attracts expatriate Pakistani neurologists and delegates from neighboring countries. The official journal of the PSN is the Pakistan Journal of Neurological Sciences

From the Section of Neurology (M.W.), Department of Medicine, Aga Khan University, Karachi; and Division of Neurology (I.A.K.), Shifa International Hospital, Islamabad, Pakistan.

Go to Neurology.org for full disclosures. Funding information and disclosures deemed relevant by the authors, if any, are provided at the end of the article. 
(www.pakjns.com) and is indexed with PMDC. There are 2 national forums for trainees and neurologists. PSN meetings accommodate about 30 to 40 original research presentations every year and the Annual Neurology Research Day for Medical Students and Residents in Islamabad has been held for 5 years. Unfortunately, very few papers are published from the neurology community in international journals.

The Pakistan International Neuroscience Society and the neurology group within the Association of Pakistani Physicians in North America are actively supporting neurologic training by online and video conferencing. Funding for research and advocacy in Pakistan could make a significant difference. The Pakistani neurology community is active in international neurology platforms, especially the World Federation of Neurology, the American Academy of Neurology, the World Stroke Organization, and the Asian Oceanic Organization of Neurology. PSN will advocate for mandatory neurology education in medical colleges, appointments for neurology faculty at medical colleges, and positions at district hospitals.

Interest in postgraduate training in neurology has increased tremendously and the largest number of local graduates in neurology was recently reported. PSN is working with the College of Physicians and Surgeons to increase the number of accredited training centers and neurology trainee positions in Pakistan. The current number of training centers is 16 with 104 trainees and we want to increase this number to 30 centers with 240 trainees over 3 years. We expect to have more than 500 trained neurologists in Pakistan by 2017. We are also focusing on subspecialty training in neurology. Aga Khan University has received NIH funding (approximately \$500,000 USD) for training stroke neurologists in Pakistan. We are working with the Pakistan International Neuroscience Society to start epilepsy, multiple sclerosis, Parkinson disease, and dementia fellowships in Pakistan over the next 3 years.

Neurologic research is another priority area for PSN. Neurologic research in Pakistan is largely limited to stroke and CNS infections. Our aim is improve research capacity by providing some funding for relevant research in Pakistan. Public awareness activities are one of the most highlighted areas of PSN. World Stroke Day and Epilepsy Day attract much media coverage. The
PSN regularly organizes public awareness programs on various topics at different cities in Pakistan. The PSN established a task force for tetanus and rabies eradication from Pakistan, which is collaborating with the ministry of health, city governments, media, and infectious diseases society of Pakistan for this cause.

We are also making an effort to promote academic foundations of neurology through applied research, establishment of stringent standards for training and qualification, and ensuring professional dialog and continued medical education. Guidelines for safe, ethical, and effective clinical practice are being developed to promote and protect the neurologic health of the community. Liaison with Pakistani neurologists overseas and regional and international professional societies are being established and strengthened to help achieve the goals. Despite the limitations, there is great hope for neurology in Pakistan.

\section{AUTHOR CONTRIBUTIONS}

Dr. Wasay: concept, data collection, manuscript writing, manuscript revision. Dr. Khatri: data collection, manuscript writing, manuscript review.

\section{STUDY FUNDING}

No targeted funding reported.

\section{DISCLOSURE}

The authors report no disclosures relevant to the manuscript. Go to Neurology. org for full disclosures.

\section{REFERENCES}

1. Khatri IA. 18 years old - time for national identification. Pak J Neurol Sci 2011;6:iv-vi.

2. Shafqat S. Neurology in Pakistan-a vision. Pak J Neurol Sci 2006;1:159-161.

3. Hayat M, Baig SM, Ali S, Haq A. Future of neurology in Pakistan. J Pak Med Assoc 2003;53:576-579.

4. Wasay M. Future of neurology in Pakistan. Pak J Neurol Sci 2010;5:iv-v

5. Wasay M, Ali S. Growing burden of neurological diseases in Pakistan-need for a national health survey. J Pak Med Assoc 2010;60:249-250.

6. Khealani BA, Wasay M. Burden of stroke in Pakistan. Int J Stroke 2008;3:293-296.

7. Wasay M, Khatri I, Salahuddin N. Tetanus and rabies eradication in Pakistan: a mission not impossible. J Pak Med Assoc 2008;58:158-159.

8. Ibrahim S. Pediatric neurology in the 21st century: its outlook in Pakistan. Pak J Neurol Sci 2011;6:1-2. 


\section{Neurology}

\section{Neurology in Pakistan: Growing burden, low on priority, and a hope to keep alive Mohammad Wasay and Ismail A. Khatri \\ Neurology 2013;80;581-582 \\ DOI 10.1212/WNL.0b013e3182815403}

This information is current as of February 4, 2013

\author{
Updated Information \& \\ Services
}

References

Subspecialty Collections

Permissions \& Licensing

Reprints including high resolution figures, can be found at: http://n.neurology.org/content/80/6/581.full

This article cites 8 articles, 0 of which you can access for free at: http://n.neurology.org/content/80/6/581.full\#ref-list-1

This article, along with others on similar topics, appears in the following collection(s):

All epidemiology

http://n.neurology.org/cgi/collection/all_epidemiology

All Health Services Research

http://n.neurology.org/cgi/collection/all_health_services_research Health systems

http://n.neurology.org/cgi/collection/health_systems

Underserved populations

http://n.neurology.org/cgi/collection/underserved_populations

Information about reproducing this article in parts (figures,tables) or in its entirety can be found online at:

http://www.neurology.org/about/about_the_journal\#permissions

Information about ordering reprints can be found online:

http://n.neurology.org/subscribers/advertise

Neurology ${ }^{\circledR}$ is the official journal of the American Academy of Neurology. Published continuously since 1951 , it is now a weekly with 48 issues per year. Copyright @ 2013 American Academy of Neurology. All rights reserved. Print ISSN: 0028-3878. Online ISSN: 1526-632X.

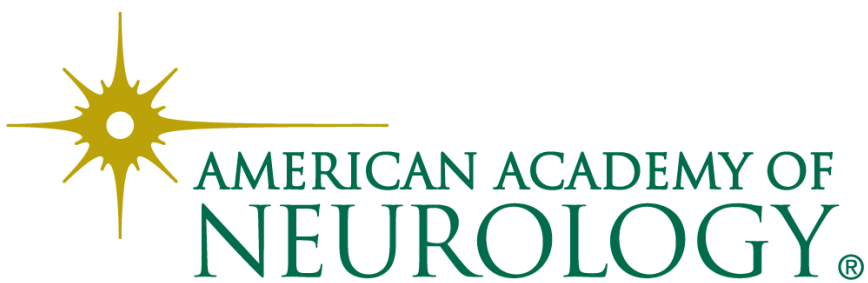

